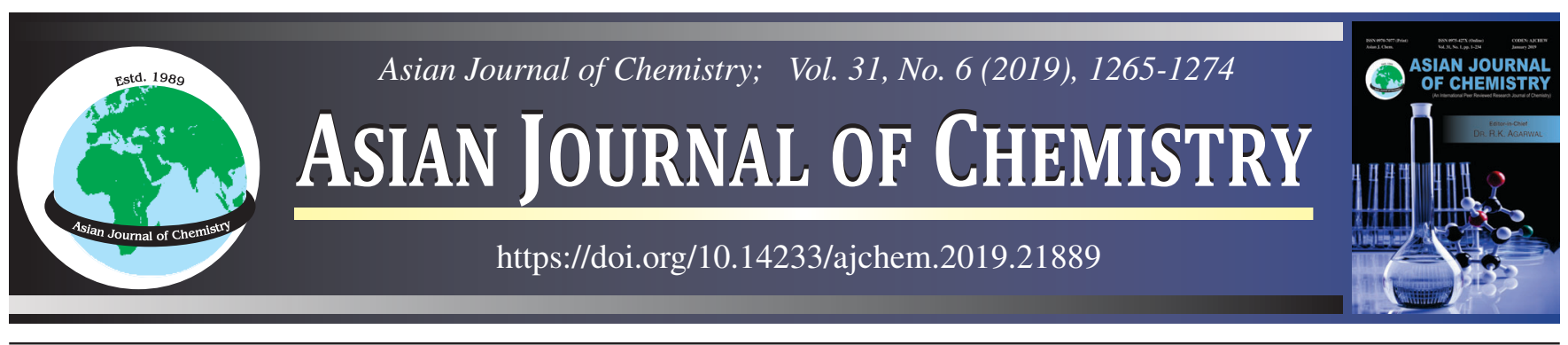

\title{
Studies on DNA Interactions and Biological Activities of Lanthanum(III) Complexes with 4-Quinoline Terpyridine and 1,10-Phenanthroline
}

\section{P.R. Chetana ${ }^{1, *}$, D.R. Navya ${ }^{1}$, Vibha Vinayakumar Bhat ${ }^{1}$, B.S. Srinatha ${ }^{2}$ and Mohan A. Dhale ${ }^{3}$}

${ }^{1}$ Department of Chemistry, Central College Campus, Bangalore University, Bengaluru-560001, India

${ }^{2}$ Department of Chemistry, Forensic Science Laboratory, Bengaluru-560068, India

${ }^{3}$ Department of Microbiology and Fermentation Technology, Central Food Technological Research Institute, Mysore-570020, India

*Corresponding author: E-mail: pr.chetana@gmail.com

Received: 23 December 2018;

Accepted: 4 February 2019;

Published online: 29 April 2019;

AJC-19367

| A series of lanthanum(III) complexes [La(4-qtpy $\left.)_{2}\left(\mathrm{NO}_{3}\right)_{2}\right]\left(\mathrm{NO}_{3}\right)(\mathbf{1}),\left[\mathrm{La}(4-\mathrm{qtpy})_{3}\left(\mathrm{NO}_{3}\right)\right]\left(\mathrm{NO}_{3}\right)_{2}(2),\left[\mathrm{La}(4-\mathrm{qtpy})(\mathrm{phen})\left(\mathrm{NO}_{3}\right)_{2}\right]\left(\mathrm{NO}_{3}\right)(3)$ and $\left[\mathrm{La}(4-q t p y)(\text { phen })_{2}\left(\mathrm{NO}_{3}\right)_{2}\right]\left(\mathrm{NO}_{3}\right)$ (4) (4-qtpy $=4^{\prime}$-[(4-quinoline)-2, $2^{\prime} ; 6^{\prime}, 2^{\prime \prime}$-terpyridine $\left.]\right)$ were synthesized and characterized. The cyclic voltammetric studies revealed that the complexes $\mathbf{1}$ and $\mathbf{3}$ are redox active. UV-visible absorption spectral studies and viscosity measurements revealed that complexes bind to DNA through intercalation. Complexes $\mathbf{1}$ and $\mathbf{3}$ have shown the highest binding propensity I $\left(K_{b}=4.241+0.2 \times 10^{6}\right.$ for $\mathbf{1}$ and $1.492+0.2 \times 10^{6}$ for $\left.\mathbf{3}\right)$. The results of chemical nuclease studies revealed that the complexes $\mathbf{3}$ and $\mathbf{4}$ have shown maximum chemical nuclease activity in the presence of $\mathrm{H}_{2} \mathrm{O}_{2}$ and the mechanism involves hydroxyl radicals. The antibacterial activities of the complexes $\mathbf{1}$ to $\mathbf{4}$ were tested against Gram positive and Gram negative bacteria in which complex $\mathbf{3}$ shows comparable results with the standard antibiotic tetracycline. The cytotoxic activities of 4-qtpy and complex 4 were done by MTT assay against HeLa cell lines.

Keywords: Terpyridine complexes, Lanthanum(III) complexes, Antibacterial activity, Cytotoxic study.

ᄂ _ - - - - - - - - - - - - - - - - - - - - - - - - - - - - -

\section{INTRODUCTION}

Owing to their strong $\pi$-stacking ability, coordination abilities and directional $\mathrm{H}$-bonding, terpyridine and its derivatives are prominent building blocks in organic as well as inorganic chemistry [1,2]. Substituted terpyridines are versatile ligands because they form complexes with $d$ - and $f$-block metals. They find applications in various fields like asymmetric catalysis, luminescent functional materials, optical nanodevices, photosensitization, solar cells, molecular switches and medical probes $[3,4]$. Terpyridine complexes are extensively studied due to their unique luminescent properties as well as biological activities, such as interaction with biomolecules having potential applications in anticancer, antimicrobial agents and radiotherapy with a specific inclination to bind with nucleic acids $[5,6]$. The coordinated terpyridines play a vital role in the antitumor activity of the metallo-drugs because they can modify key parameters such as lipophilicity and reactivity of metal complexes [5].
The 2,2':6',2" -terpyridine is a tridentate nitrogen containing coplanar ligand and rarely it can act as mono or bidentate ligand. The choice of this ligand is primarily due to their planar structure. Due to planar structure insertion of complexes takes place in between base pairs of DNA and hence are deliberated as good metallo-intercalators [7,8]. Additionally, the introduction of different groups at $4^{\prime}$-position of $2,2^{\prime}: 6^{\prime}, 2^{\prime \prime}$-terpyridine results in the modification of photophysical and DNA interaction ability of the complexes. Hence, the chemistry of terpyridine is a dynamic and emergent area of attentiveness in the fields of medicinal and bioinorganic chemistry [9]. 1,10-Phenanthroline is a rigid planar heterocyclic base, which can be used as DNA intercalator. Metal complexes containing 1,10-phenanthroline are well known for DNA binding through intercalative mode. So, we choose to synthesize La(III) complexes with these ligands [10].

Lanthanum(III) complexes have been employed in various biological and as well as photophysical applications. La(III)

This is an open access journal, and articles are distributed under the terms of the Creative Commons Attribution-NonCommercial-ShareAlike 4.0 (CC BY-NC-SA 4.0) International License which allows readers to freely read, download, copy, distribute, print, search, or link to the full texts of its articles and to use them for any other lawful non-commercial purpose as long as the original source is duly acknowledged. 
complexes with quercetin [11], Schiff bases [12], oxamides [13], norfloxacin [14], derivatives of phenanthroline have been employed as chemical nucleases [15], DNA binding agents [16], antimicrobial [13] and anticancer agents [7,11]. Lanthanum(III) complexes have also shown ligand dependent photoluminescence properties $[17,18]$. But La(III) complexes having terpyridine as ligands are less explored. In this view, we have synthesized new complexes with lanthanum containing 4quinoline terpyridines and 1,10-phenanthroline. We have tested these newly synthesized complexes for their chemical nuclease activity against supercoiled (SC) pUC 19 DNA, binding abilities towards Herring sperm (HS) DNA, antibacterial activities against Gram positive (Bacillus subtilis and Staphylococcus aureus) and Gram negative (Escherichia coli and Klebsiella pneumoniae) bacteria and cytotoxicity against HeLa cell lines. The complexes 1-4 have also been tested for their photoluminescence properties.

In this present work, we report the syntheses and characterization of $\mathrm{La}$ (III) complexes with 4-quinoline terpyridine ligand. The DNA binding properties of the complexes have been investigated by UV-visible absorption titration and viscosity measurements. The DNA cleavage of the complexes have been investigated by agarose gel electrophoresis method. These complexes exhibit cytotoxic effects against HeLa cell lines and bactericidal action against tested bacteria.

\section{EXPERIMENTAL}

All the reagents and solvents were commercially available and used as received. Supercoiled (SC) pUC19 DNA (caesium chloride purified), herring sperm-DNA (HS-DNA) were purchased from Bangalore Genie (India). Agarose (molecular biology grade), ethidium bromide were purchased from Sigma (USA). Tris(hydroxymethyl)aminomethane- $\mathrm{HCl}$ (Tris-HCl) buffer was prepared using deionized and sonicated triple distilled water. Bacterial media was purchased from Himedia. The bacterial strains were procured from IMTECH, Chandigarh, India. All the cell lines for MTT assay were purchased from ATCC.

General procedure: The lanthanum complexes were prepared by modified reported method. The ligand 4-qtpy was synthesized [19] for the comparative study with the newly synthesized complexes 1-4.

Synthesis of lanthanum(III) complexes 1-2: The complexes 1 and $\mathbf{2}$ were prepared by following modified reported method using varied concentrations of ligand 4-qtpy [20]. $\mathrm{La}\left(\mathrm{NO}_{3}\right)_{3}$. $6 \mathrm{H}_{2} \mathrm{O}(0.030 \mathrm{~g}, 0.69 \mathrm{mM})$ and 4-qtpy $(0.050 \mathrm{~g}, 0.138 \mathrm{mM}$ for $1 ; 0.075 \mathrm{~g}, 2.07 \mathrm{mM}$ for 2 , respectively) were dissolved in 10 $\mathrm{mL}$ dry or air free methanol, refluxed for $4 \mathrm{~h}$ at $60^{\circ} \mathrm{C}$ with stirring under nitrogen atmosphere. Then the solution was allowed to dry to obtained off-white complexes, washed with $5 \mathrm{~mL}$ diethyl ether and dried under vacuum. The complexes were soluble in $\mathrm{MeOH}, \mathrm{DMF}$ and DMSO.

Elemental analysis calcd. (found) $\%$ for $\mathrm{C}_{48} \mathrm{H}_{32} \mathrm{~N}_{11} \mathrm{O}_{9} \mathrm{La}$ [La(4-qtpy) $\left.{ }_{2}\left(\mathrm{NO}_{3}\right)_{2}\right]\left(\mathrm{NO}_{3}\right)$ (1): C, 55.13 (55.02); H, 3.08 (3.06); $\mathrm{N}, 4.73$ (14.68). FT-IR (KBr disc, $v_{\max }, \mathrm{cm}^{-1}$ ): $1600 \mathrm{~m}, 1536$ w, $1455 \mathrm{~m}, 1392 \mathrm{~m}, 1288 \mathrm{w}, 1032 \mathrm{~m}, 1067 \mathrm{~m}, 857$ w, $796 \mathrm{~m}$, $623 \mathrm{~m}, 567$ w. UV-visible in DMF $\left[\lambda_{\max }, \mathrm{nm}\left(\varepsilon, \mathrm{M}^{-1} \mathrm{~cm}^{-1}\right)\right]$ : $266(66,333) . \Lambda_{\mathrm{M}}\left(\mathrm{S} \mathrm{cm}^{2} \mathrm{M}^{-1}\right)$ in DMF at $25^{\circ} \mathrm{C}$ 92.2. ESI-MS in methanol $m / z$ : $982.62\left[\mathrm{M}-\left(\mathrm{NO}_{3}{ }^{-}\right)\right]^{+}$. ${ }^{1} \mathrm{H}$ NMR $(400 \mathrm{MHz}$,
DMSO- $d_{6}, \delta$ ppm) 7.517-7.547 (4H, m), 7.642-7.690 (4H, m), 7.84-7.878 (2H, t), 7.927-7.948 (2H, d), 8.045-8.086 (4H, t), 8.172-8.193 (2H, d), $8.568(4 \mathrm{H}, \mathrm{s}), 8.708-8.744(8 \mathrm{H}, \mathrm{m})$, 9.041-9.052 (2H, d); Yield: $58 \%$.

Elemental analysis for calcd. (found) $\%$ for $\mathrm{C}_{72} \mathrm{H}_{48} \mathrm{~N}_{15} \mathrm{O}_{9} \mathrm{La}$ $\left[\mathrm{La}(4-\mathrm{qtpy})_{3}\left(\mathrm{NO}_{3}\right)\right]\left(\mathrm{NO}_{3}\right)_{2}$ (2): C, $61.50(61.38) ; \mathrm{H}, 3.44$ (3.41); N, $14.94(14.88) \%$. FT-IR (KBr disc, $\left.\nu_{\max }, \mathrm{cm}^{-1}\right): 1579 \mathrm{~s}, 1507$ w, 1460 s, 1387 s, 1297 m, 1036 w, 861 w, 784 s, 737 s, 628 s, 540 w. UV-visible in DMF $\left[\lambda_{\max }, \mathrm{nm}\left(\varepsilon, \mathrm{M}^{-1} \mathrm{~cm}^{-1}\right)\right]: 265$ $(52,533) . \Lambda_{\mathrm{M}}\left(\mathrm{S} \mathrm{cm}^{2} \mathrm{M}^{-1}\right)$ in DMF at $25^{\circ} \mathrm{C} 142.4$. ESI-MS in methanol $\mathrm{m} / z$ : $639.23\left[\mathrm{M}-2\left(\mathrm{NO}_{3}^{-}\right)^{-}\right]^{2+} .{ }^{1} \mathrm{H}$ NMR $(400 \mathrm{MHz}$, DMSO- $\left.d_{6}, \delta \mathrm{ppm}\right):$ 7.536-7.569 $(6 \mathrm{H}, \mathrm{m}), 7.666-7.715(6 \mathrm{H}$, m), 7.859-7.900 (3H, t), 7.950-7.971 (3H, d), 8.065-8.108 (6H, td), 8.193-8.214 (3H, d), 8.594 (6H, s), 8.729-8.766 (12H, t), 9.064-9.075 (3H, d); Yield: $64 \%$.

Synthesis of lanthanum(III) complexes (3-4): Complexes 3 and $\mathbf{4}$ were prepared by following modified reported method using varied concentrations of 1,10-phenanthroline [20]. 4qtpy $(0.050 \mathrm{~g}, 0.138 \mathrm{mM})$ and $\mathrm{La}\left(\mathrm{NO}_{3}\right)_{3} \cdot 6 \mathrm{H}_{2} \mathrm{O}(0.030 \mathrm{~g}, 0.138$ $\mathrm{mM}$ ) were dissolved in $10 \mathrm{~mL}$ dry or air free methanol refluxed for $4 \mathrm{~h}$ at $60^{\circ} \mathrm{C}$ with stirring under nitrogen atmosphere. Then the methanolic solution of 1,10-phenanthroline $(0.012 \mathrm{mg}$, $0.138 \mathrm{mM}$ for 3 and $0.025 \mathrm{~g}, 0.276 \mathrm{mM}$ for 4, respectively) was added drop wise to the solution and stirred for an additional $2 \mathrm{~h}$. The solution was allowed to dryness to yielded off-white solid which was washed with $5 \mathrm{~mL}$ diethyl ether and finally dried under vacuum. The complexes were soluble in $\mathrm{MeOH}$, DMF and DMSO.

Elemental analysis calcd. (found) $\%$ for $\mathrm{C}_{36} \mathrm{H}_{24} \mathrm{~N}_{9} \mathrm{O}_{9} \mathrm{La}$ [La(4-qtpy)(phen) $\left.\left(\mathrm{NO}_{3}\right)_{2}\right]\left(\mathrm{NO}_{3}\right)(3)$ : C, 49.96 (49.82); H, 2.79 (2.76); N, 14.56 (14.52). FT-IR (KBr disc, $\left.v_{\max }, \mathrm{cm}^{-1}\right): 1578 \mathrm{w}$, $1544 \mathrm{w}, 1454 \mathrm{~s}, 1390 \mathrm{~m}, 1298 \mathrm{~m}, 1028 \mathrm{~m}, 840 \mathrm{~s}, 724$ s, $613 \mathrm{~m}$, 536 w. UV-visible in DMF $\left[\lambda_{\max }, \mathrm{nm}\left(\varepsilon, \mathrm{M}^{-1} \mathrm{~cm}^{-1}\right)\right]: 264(66,333)$. $\Lambda_{\mathrm{M}}\left(\mathrm{S} \mathrm{cm}^{2} \mathrm{M}^{-1}\right)$ in DMF at $25^{\circ} \mathrm{C}$ : 94.8 . ESI-MS in methanol $m / z: 802.77\left[\mathrm{M}-\left(\mathrm{NO}_{3}{ }^{-}\right)\right]^{+} .{ }^{1} \mathrm{H} \mathrm{NMR}\left(400 \mathrm{MHz}, \mathrm{DMSO}-d_{6}, \delta \mathrm{ppm}\right)$ : 7.522-7.552 (2H, dd), 7.646-7.687 (2H, m), $7.698(1 \mathrm{H}, \mathrm{m})$, 7.77-7.801 $(1 \mathrm{H}, \mathrm{m})$ 7.845-7.883 (2H, td $), 7.931-7.951(2 \mathrm{H}, \mathrm{d})$, $8.002(1 \mathrm{H}, \mathrm{s}), 8.048-8.091$ (3H, td), 8.175-8.196 (1H, d), 8.495$8.518(1 \mathrm{H}, \mathrm{d}), 8.572(2 \mathrm{H}, \mathrm{s}), 8.711-8.748(5 \mathrm{H}, \mathrm{m}), 9.045-9.056$ $(1 \mathrm{H}, \mathrm{d}), 9.100-9.911(1 \mathrm{H}, \mathrm{d})$; Yield: $53 \%$.

Elemental analysis calcd. (found) $\%$ for $\mathrm{C}_{48} \mathrm{H}_{32} \mathrm{~N}_{11} \mathrm{O}_{9} \mathrm{La}$ $\left[\mathrm{La}(4-q\right.$ tpy $\left.)(\text { phen })_{2}\left(\mathrm{NO}_{3}\right)_{2}\right]\left(\mathrm{NO}_{3}\right)(4): \mathrm{C}, 55.13(55.04) ; \mathrm{H}, 3.08$ (3.05); $\mathrm{N}, 14.73$ (14.68). FT-IR (KBr disc, $\left.\nu_{\max }, \mathrm{cm}^{-1}\right): 1582 \mathrm{~s}$, $1541 \mathrm{w}, 1458 \mathrm{~m}, 1388 \mathrm{~s}, 1291 \mathrm{~m}, 1034 \mathrm{w}, 852 \mathrm{w}, 784 \mathrm{vs}, 730$ $\mathrm{s}, 617 \mathrm{vs}, 572 \mathrm{w}$. UV-visible in DMF $\left[\lambda_{\max }, \mathrm{nm}\left(\varepsilon, \mathrm{M}^{-1} \mathrm{~cm}^{-1}\right)\right]$ : $265(52,533) . \Lambda_{\mathrm{M}}\left(\mathrm{S} \mathrm{cm}^{2} \mathrm{M}^{-1}\right)$ in DMF at $25^{\circ} \mathrm{C}: 118.2$. ESI-MS in methanol $m / z: 982.67\left[\mathrm{M}-\left(\mathrm{NO}_{3}^{-}\right)\right] .{ }^{1} \mathrm{H}$ NMR $(400 \mathrm{MHz}$, DMSO- $\left.d_{6}, \delta \mathrm{ppm}\right) 7.556-7.571(2 \mathrm{H}, \mathrm{m}), 7.683-7.719(2 \mathrm{H}, \mathrm{m})$, 7.780-7.811 $(4 \mathrm{H}, \mathrm{m}), 7.863-7.884(1 \mathrm{H}, \mathrm{td}) 7.951-7.972(1 \mathrm{H}$, dd), 8.015 (4H, s), 8.066-8.110 (4H, td), 8.194-8.214 (2H, d), 8.503-8.528 (1H, dd), $8.595(2 \mathrm{H}, \mathrm{s}), 8.728-8.768(4 \mathrm{H}, \mathrm{m})$, 9.066-9.077 (1H, d), 9.114-9.119 (4H, dd); Yield: $68 \%$.

Detection method: The elemental analyses of the newly synthesized complexes 1-4 were done, using a Thermo Finnigan FLASH EA 1112 CHNS analyzer. The calculated values are correlated with the observed values. Molar conductivity measurements were carried out by Control Dynamics (India) conductivity meter. The FT-IR spectra of the complexes were recorded on 
Perkin Elmer Lambda 35 spectrophotometer in the range 4000$500 \mathrm{~cm}^{-1}$. The fluorescence emission spectral measurements of the 4-qtpy and its $\mathrm{La}(\mathrm{III})$ complexes in DMF/Tris-HCl buffer are carried out at wavelength ranging from 300 to $550 \mathrm{~nm}$ using Jasco spectrofluorometer at an excitation wavelength around $290 \mathrm{~nm} .{ }^{1} \mathrm{H}$ NMR (Bruker, $400 \mathrm{MHz}$ ) spectra of the complexes were recorded in DMSO- $d_{6}$ solution using tetramethylsilane (TMS) as internal standard. ESI-Mass spectrometry of the complexes were performed on a Bruker Esquire 6000 (ESI) mass spectrometer.

DNA binding studies: By using electronic absorption spectra and viscosity measurements, the binding propensities of complexes with HS-DNA were measured. UV-visible absorption measurements of the complexes in DMF/Tris-HCl buffer were carried out at wavelengths ranging from 200 to $800 \mathrm{~nm}$ using Shimadzu UV-1800 PC spectrophotometer.

UV-Visible absorption titration: The binding interaction study of La(III) complexes (1-4) with HS-DNA were measured using Tris- $\mathrm{HCl} / \mathrm{NaCl}$ buffer ( $5 \mathrm{mM}$ Tris- $\mathrm{HCl}, 5 \mathrm{mM} \mathrm{NaCl}, \mathrm{pH}$ 7.2). The purity of HS-DNA in Tris- $\mathrm{HCl} / \mathrm{NaCl}$ buffer was measured at 260 and $280 \mathrm{~nm}$, gave a ratio of 1:1.9 showed that DNA was protein free [21]. The concentration of DNA was calculated from its known molar extinction $(\varepsilon)$ value of $6,600 \mathrm{M}^{-1} \mathrm{~cm}^{-1}$. Stock solutions of the complexes were prepared by DMF and diluted with Tris- $\mathrm{HCl}$ buffer to obtain required concentration of the complexes. The electronic absorption titrations were measured with increasing concentration of HSDNA with constant complex concentration $(15 \mu \mathrm{M})$. Before recording the spectrum, samples were equilibrated to bind sufficiently to DNA. The intrinsic binding constant $\left(\mathrm{K}_{\mathrm{b}}\right)$ was determined by using the equation [3]:

$$
\frac{[\mathrm{DNA}]}{\left(\varepsilon_{\mathrm{a}}-\varepsilon_{\mathrm{f}}\right)}=\frac{[\mathrm{DNA}]}{\left(\varepsilon_{\mathrm{b}}-\varepsilon_{\mathrm{f}}\right)}+\frac{1}{\mathrm{~K}_{\mathrm{b}}\left(\varepsilon_{\mathrm{a}}-\varepsilon_{\mathrm{f}}\right)}
$$

where, molar absorptivity of the complexes after each addition of DNA, $\varepsilon_{\mathrm{f}}=$ molar absorptivity of free; $\varepsilon_{\mathrm{a}}=$ apparent complexes and $\varepsilon_{b}=$ molar absorptivity of complexes in fully bound form with DNA. A plot of [DNA] $/ \varepsilon_{\mathrm{a}}-\varepsilon_{\mathrm{f}}$ versus [DNA] gives $\mathrm{K}_{\mathrm{b}}$ as the ratio of slope to the intercept.

Viscosity measurements: Viscometric experiments were performed at $37( \pm 0.1){ }^{\circ} \mathrm{C}$ in a constant temperature bath. In these experiments, the rate of flow of $5 \mathrm{mM}$ Tris-HCl buffer (pH 7.2), HS-DNA and La(III) complexes with DNA at various concentrations were measured. The relative specific viscosity of HS-DNA was calculated using the equation $\eta=\mathrm{t}-\mathrm{t}_{\mathrm{o}} / \mathrm{t}_{\mathrm{o}}$ where $t$ is the perceived flow time of DNA in the presence and absence of the complexes, $t_{o}$ is the flow time of buffer alone. A graph of $\left(\eta / \eta_{0}\right)^{1 / 3} v s$. [complex]/[DNA] was plotted, where $\eta$ is the viscosity of DNA with the complexes and $\eta_{0}$ is the viscosity of DNA alone [22,23].

DNA cleavage experiments: The chemical nuclease activity of 4-qtpy and its complexes 1-4 with super-coiled pUC 19 DNA was monitored by agarose gel electrophoresis method using $50 \mathrm{mM}$ Tris-HCl/ $\mathrm{NaCl}$ buffer $(\mathrm{pH}=7.2)$. The extent of cleavage of super-coiled pUC 19 DNA into nick circular (NC) form by complexes at $10 \mu \mathrm{M}$ concentration in the presence and absence of $\mathrm{H}_{2} \mathrm{O}_{2}$ and MPA, was studied [24]. The samples were incubated for $90 \mathrm{~min} .0 .8 \%$ agarose gel was prepared by dissolving $0.25 \mathrm{~g}$ in $25 \mathrm{~mL}$ 1XTAE buffer then by adding $1.0 \mu \mathrm{g} \mathrm{mL}^{-1}$ ethidium bromide. The samples were loaded by loading dye containing $0.25 \%$ bromophenol blue, $0.25 \%$ xylene cyanol and $30 \%$ glycerol $(2 \mu \mathrm{L})$. The experiment was carried out in dark for $90 \mathrm{~min}$ at $45 \mathrm{~V}$ in TAE buffer and photographed. By measuring the intensities of the bands using a UVITECH Gel Documentation System, the extent of cleavage of SC-DNA was determined. Due corrections were made for the low level of nick circular form present in the original supercoiled-DNA sample and for the low affinity of ethidium bromide binding to super-coiled compared to nick circular and linear forms of DNA. Mechanistic studies were carried out with different additives such as DMSO (hydroxyl radical quencher), $\mathrm{NaN}_{3}$ (singlet oxygen quencher) and with the major groove binder methyl green $[13,25]$.

Antibacterial activity: The antibacterial assays for $4^{\prime}-$ [(4-quinoline)-2, $2^{\prime} ; 6^{\prime}, 2^{\prime \prime}$-terpyridine] (4-qtpy) and its La(III) complexes 1-4 were carried out by disc diffusion method using Gram positive bacteria (Bacillus subtilis MTCC 645 and Staphylococcus aureus MTCC 3160) and Gram negative bacteria (Escherichia coli ATCC 25922 and Klebsiella pneumoniae MTCC 109) as test organisms. The compounds were dissolved in DMSO $\left(1 \mathrm{mg} \mathrm{mL}^{-1}\right)$ for the assay. Antibacterial activity was determined in Whatman filter paper discs containing 50 and $100 \mu \mathrm{g} \mathrm{mL}{ }^{-1}$ of the samples incubated at $37^{\circ} \mathrm{C}$ for $24 \mathrm{~h}$. After $24 \mathrm{~h}$ zone of inhibition were measured [26]. Tetracycline and DMSO were used as positive and negative controls, respectively.

Cytotoxic study: To evaluate the effect of compounds on the cell growth, the cytotoxic studies of 4-qtpy and complex 4 were tested on human cervical carcinoma cell line (HeLa) by using [3-(4,5-dimethylthiazol-2-yl)-2,5-diphenyl tetrazolium bromide] (MTT) assay. $100 \mu \mathrm{L}$ of diluted cell suspension $(50,000$ cells/well $)$ was seeded using respective media containing $10 \%$ fetal bovine serum (FBS) in the 96 well plate. After $24 \mathrm{~h}$ the monolayer was washed with medium and then $100 \mu \mathrm{L}$ of test drugs at different concentrations were added. The plates were incubated in $5 \% \mathrm{CO}_{2}$ atomosphere at $37^{\circ} \mathrm{C}$ for $24 \mathrm{~h}$. The test solution was discarded after incubation and $100 \mu \mathrm{L}$ of MTT was added (6 mg/10 mL of MTT in PBS) to each well. The well plates were again incubated for additional $4 \mathrm{~h}$ at $37^{\circ} \mathrm{C}$ in $5 \% \mathrm{CO}_{2}$ incubator. The supernatant was removed and $100 \mu \mathrm{L}$ of DMSO was added and the plates were gently shaken to solubilize the formed formazan. The absorbance of each well was measured using a microplate reader at the wavelength of $590 \mathrm{~nm}$. The percentage growth inhibition was calculated by the formula:

$$
\text { Inhibition }(\%)=100-\frac{\text { OD of sample }}{\text { OD of control }} \times 100
$$

The $\mathrm{IC}_{50}$ (concentration of test drug needed to inhibit cell growth by $50 \%$ ) values are generated from the dose-response curves for cell lines [11].

\section{RESULTS AND DISCUSSION}

Synthesis of bis[4'-(4-quinoline) $2,2^{\prime} ; 6^{\prime}, 2^{\prime \prime}$-terpyridine]bis(nitrato)lanthanum(III) nitrate $\left[\mathrm{La}(4-\mathrm{qtpy})_{2}\left(\mathrm{NO}_{3}\right)_{2}\right]\left(\mathrm{NO}_{3}\right)(\mathbf{1})$ and tris $\left[4^{\prime}\right.$-(4-quinoline) $2,2^{\prime} ; 6^{\prime}, 2^{\prime \prime}$-terpyridine](nitrato)- 
lanthanum(III) nitrate $\left[\mathrm{La}(4-\mathrm{qtpy})_{3}\left(\mathrm{NO}_{3}\right)\right]\left(\mathrm{NO}_{3}\right)_{2}$ (2): Complexes $\mathbf{1}$ and $\mathbf{2}$ are obtained in good yield. Complexes 1-2 are synthesized by refluxing $\mathrm{La}(\mathrm{III})$ nitrate $(0.69 \mathrm{mM})$ and 4-qtpy $(0.138$ $\mathrm{mM}$ for $\mathbf{1}$ and $2.09 \mathrm{mM}$ for 2) in methanol for $4 \mathrm{~h}$ at $60{ }^{\circ} \mathrm{C}$ (Scheme-I).

Synthesis of [ $4^{\prime}$-(4-quinoline) $2,2^{\prime} ; 6^{\prime}, 2^{\prime \prime}$-terpyridine](1,10-phenanthroline)bis(nitrato)lanthanum(III) nitrate [La(4-qtpy)(phen) $\left.\left(\mathrm{NO}_{3}\right)_{2}\right]\left(\mathrm{NO}_{3}\right)(3)$ and [4'-(4-quinoline)$2,2^{\prime} ; \mathbf{6}^{\prime}, 2^{\prime \prime}$-terpyridine]bis(1,10-phenanthroline)bis(nitrato) lanthanum(III) nitrate $\left[\mathrm{La}(4-q\right.$ tpy $\left.)(\text { phen })_{2}\left(\mathrm{NO}_{3}\right)_{2}\right]\left(\mathrm{NO}_{3}\right)(4)$ : Complexes $\mathbf{3}$ and $\mathbf{4}$ are obtained in good yield. Complexes 34 are prepared by refluxing $\mathrm{La}(\mathrm{III})$ nitrate $(0.138 \mathrm{mM})$ and $4-$ qtpy $(0.138 \mathrm{mM})$ in methanol for $4 \mathrm{~h}$ at $60^{\circ} \mathrm{C}$. After $4 \mathrm{~h}, 1,10$ phenanthroline is added $(0.138 \mathrm{mM}$ for 3 and $0.276 \mathrm{mM}$ for 4) and refluxed for an additional $2 \mathrm{~h}$ (Scheme-II).

The molar conductivity values suggested that the complex 2 is $1: 2$ electolyte having the conductivity value $157.2 \mathrm{Scm}^{2}$ $\mathrm{M}^{-1}$ and other complexes are 1:1 electrolytes having the values in the range 80-120 $\mathrm{Scm}^{2} \mathrm{M}^{-1}$ in DMF solvent [27].

IR spectra: The stretching vibration of $v(\mathrm{C}=\mathrm{N})$ band of 4-qtpy observed at $1562 \mathrm{~cm}^{-1}$ is shifted to $1600-1578 \mathrm{~cm}^{-1}$ in $\mathrm{La}(\mathrm{III})$ complexes. This shift towards higher wave number of about $16-38 \mathrm{~cm}^{-1}$ in the complexes specifies that coordination of ligands through nitrogen atom to La(III) metal [7,24]. The information about the possible binding modes of nitrate groups are obtained in the IR spectra of nitrato complexes. In La(III) complexes 1-4, the two asymmetric stretching bands are observed around 1460-1455 and 1298-1288 $\mathrm{cm}^{-1}$. The magnitude of separation of these two stretching is around $167-157 \mathrm{~cm}^{-1}$, indicates the bidentate coordination of nitrate groups [28]. A band observed around $1392-1388 \mathrm{~cm}^{-1}$ is indicative of ionic nitrate which is confirmed by the conductivity measurements [27].

Absorption and emission spectra: The electronic absorption spectra of the complexes (1-4) are recorded in DMF, which gives the valid information on the structural facts of complexes. In 4-qtpy, the absorption band appears at $283.13 \mathrm{~nm}$ is due to the ligand centred $\pi \rightarrow \pi^{*}$ transition, which is shifted towards the lower wavelength around $265.2-280.27 \mathrm{~nm}$ in the $\mathrm{La}(\mathrm{III})$ complexes. The weak absorption band appears at $315.26 \mathrm{~nm}$ in 4-qtpy is due to $\pi \rightarrow \pi^{*}$ transition which appears around $317 \mathrm{~nm}$ in the complexes [3]. The affinity to shift either higher or lower wavelength is owing to the coordination of 4-qtpy to $\mathrm{La}$ (III) [4]. Absorption for the complexes in DMF/Tris-HCl buffer does not show any significant changes recorded at room temperature for upto $4 \mathrm{~h}$ suggesting their stability in DMF/ Tris- $\mathrm{HCl}$ solution [3].

(a)

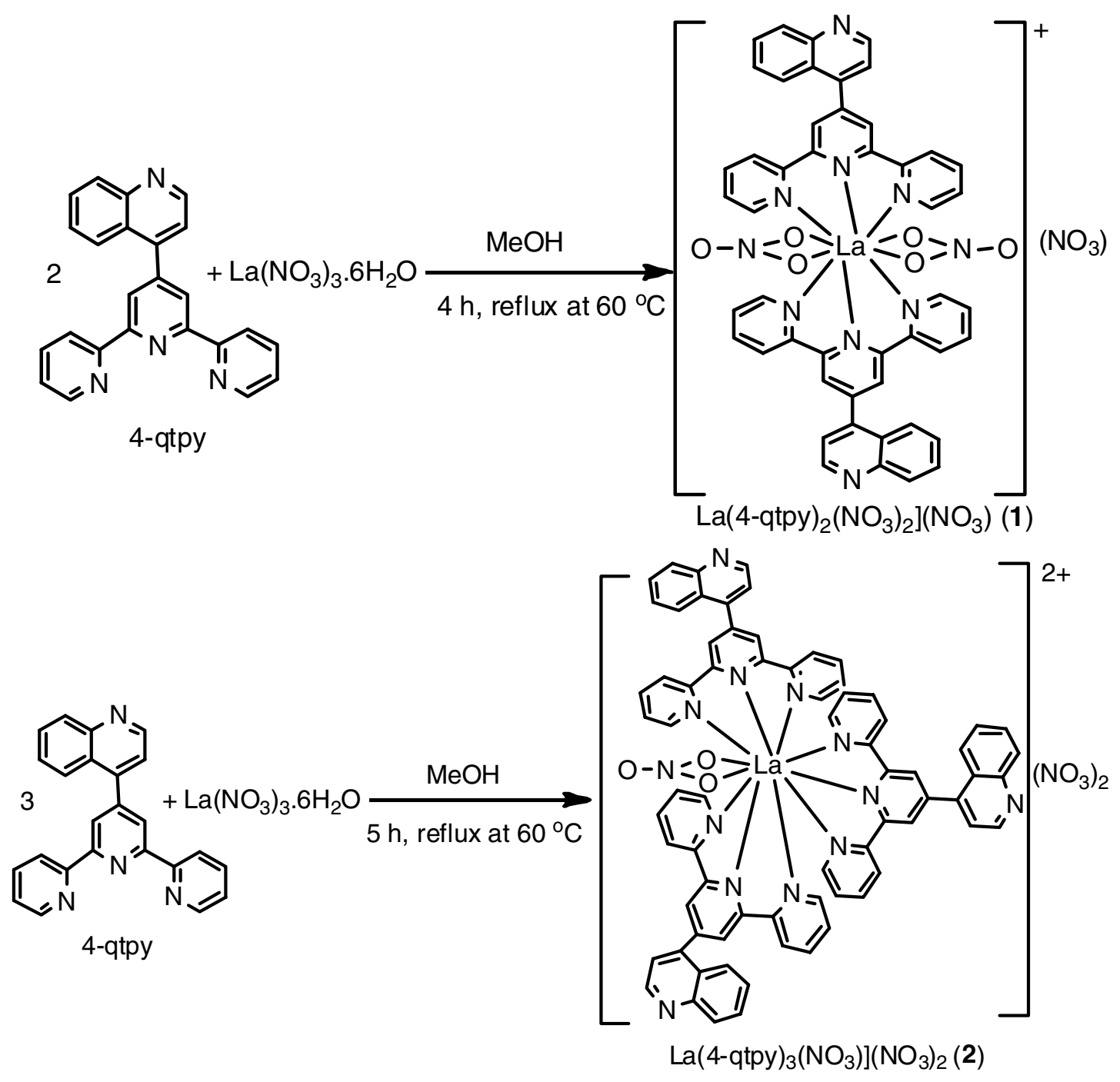

Scheme-I: (a) Preparation of complex $\mathbf{1}$ and (b) complex $\mathbf{2}$ 
(a)

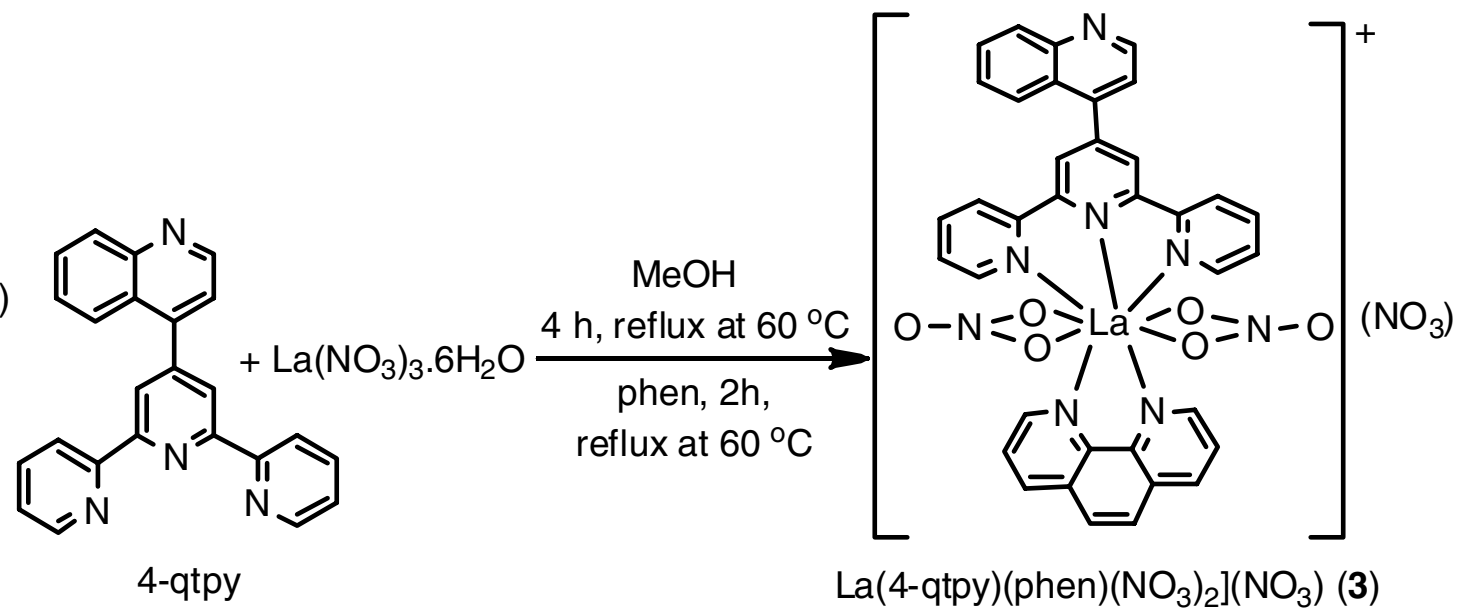

(b)

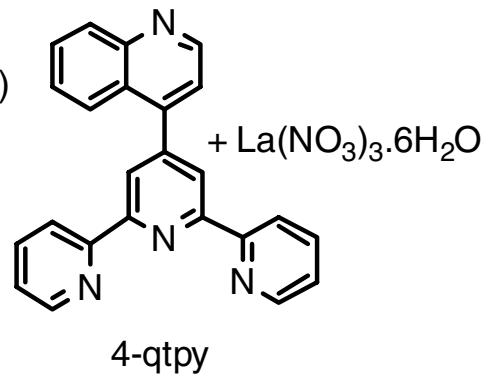

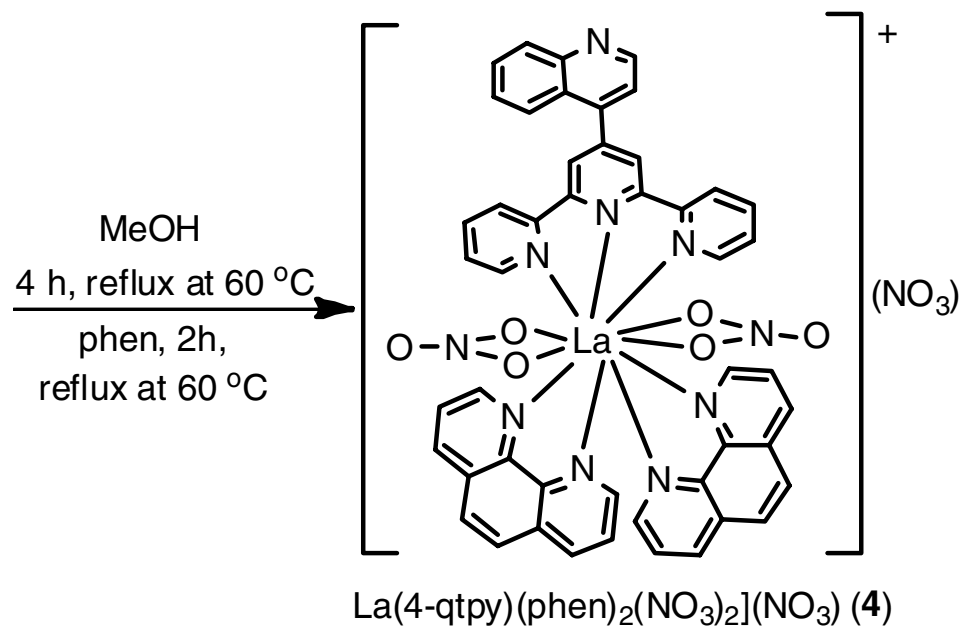

Scheme II: (a) Preparation of complex 3 and (b) complex 4

Due to $\pi \rightarrow \pi^{*}$ transition, the complexes exhibit ligand centred emission at 398,438 and $470 \mathrm{~nm}[18,29]$. In the ligand 4-qtpy and its $\mathrm{La}(\mathrm{III})$ complexes, the emission maxima are observed at $438 \mathrm{~nm}$. The complexes $\mathbf{1}$ and $\mathbf{3}$ show maximum luminescence intensity than other complexes.

${ }^{1} \mathrm{H}$ NMR spectra: In general, the structure of the La(III) complexes can be resolved from the information obtained from ${ }^{1} \mathrm{H}$ NMR spectra. In complexes $\mathbf{1}$ and $\mathbf{2}$, nine sets of signals ranging from 7.517-9.052 ppm signifies the existence of aromatic groups in the newly synthesized complexes. The $-\mathrm{C}=\mathrm{N}$ protons having chemical shift values ranging from 8.708-9.074 ppm experiences a downfield shift compared to the free ligand confirms the coordination of azomethine nitrogen to $\mathrm{La}(\mathrm{III})$ metal and hence strongly signifies the deshielding effect [4]. In complexes $\mathbf{3}$ and $\mathbf{4}$, thirteen sets of signals ranging from 7.522 to $9.129 \mathrm{ppm}$ signifies the presence of aromatic protons. The $-\mathrm{C}=\mathrm{N}$ protons having chemical shift values ranging from 8.711 to $9.129 \mathrm{ppm}$ experience a downfield shift compared to the free ligand, confirms the coordination of azomethine nitrogen to $\mathrm{La}(\mathrm{III})$ metal and hence strongly signifies the deshielding effect [30]. Owing to its highly planar and stronger deshielding effect, the protons of the phenanthroline show larger downfield shift compared to other two complexes $\mathbf{1}$ and $\mathbf{2}$. In all the La(III) complexes 1-4, the number of protons appears in ${ }^{1} \mathrm{H} N M R$ spectra correlates with the total number of protons present in the $\mathrm{La}$ (III) complexes $[8,30]$.
ESI-mass spectra: The ESI mass spectra for ligand and its $\mathrm{La}(\mathrm{III})$ complexes were recorded to confirm the proposed structure. All the spectra of $\mathrm{La}$ (III) complexes are measured in positive ion mode. The $\mathrm{m} / \mathrm{z}$ value of complex $\mathbf{2}$ corresponds to $\left[\mathrm{M}-2\left(\mathrm{NO}_{3}\right)\right]^{2+}$ and other complexes $\mathbf{1}, \mathbf{3}$ and $\mathbf{5}$ corresponds to $\left[\mathrm{M}-\left(\mathrm{NO}_{3}\right)\right]^{+}$. The ESI-mass spectral data is completely correlated with the simulated mass.

Cyclic voltammetric study: Cyclic voltammetric experiments were carried out by $\mathrm{CHI} 600 \mathrm{E}$ electrochemical instrument at room temperature in DMF. The potential range was varied from -0.4 to $0.6 \mathrm{~V}$ at different scan rate using $0.1 \mathrm{M}$ tetrabutylammonium perchlorate (TBAP) as supporting electrolyte. The reactions were carried out under oxygen free condition with a three electrode system: a glassy carbon working electrode, a saturated calomel reference electrode and a platinum wire auxillary electrode. The working electrode was polished with $1.0,0.3,0.05 \mu$ alumina and washed clearly by using distilled water prior to electrochemical measurements.

The electrochemical behaviour of La(III) terpyridine complexes are carried out by cyclic voltammetric measurements in DMF solution containing $0.1 \mathrm{M}$ TBAP. The experimental results of anodic $\left(E_{O}\right)$ and cathodic $\left(E_{R}\right)$ peak potential, potential separation $\Delta \mathrm{E}=\mathrm{E}_{\mathrm{O}}-\mathrm{E}_{\mathrm{R}}$ and diffision coefficient $(\mathrm{D})$ are given in Table-1. From Fig. 1a-c, it is shown that the peak current $\left(i_{p}\right)$ varies with the different scan rate $(10-100 \mathrm{mV})$ and is significantly correlated with the square root of scan rate $\left(\mathrm{v}^{1 / 2}\right)[31,32]$. 

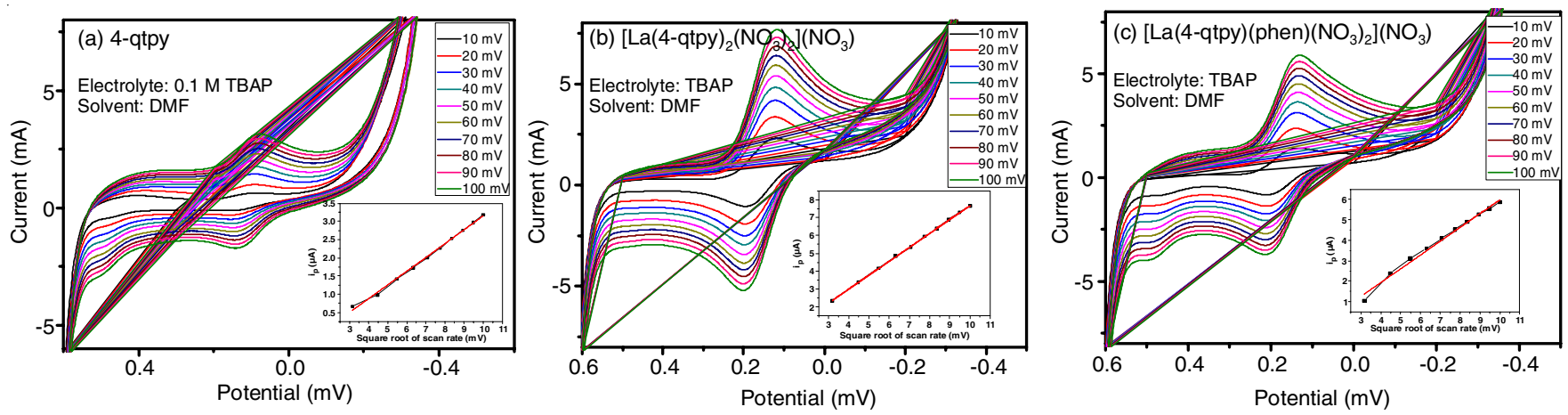

Fig. 1. Cyclic voltammogram of (a) 4-qtpy, (b) complex $\mathbf{1}$ and (c) complex $\mathbf{3}$ in DMF and TBAP is used as supporting electrolyte in the potential range -0.4 to 0.6 at the scan rate $10-100 \mathrm{mV}$ (inset show the plot of peak current $\left(\mathrm{i}_{\mathrm{p}}\right.$ ) and the square root of scan rate $\mathrm{v}^{1 / 2}$

TABLE-1

ELECTROCHEMICAL DATA OF 4-qtpy, COMPLEXES 1 AND 3

\begin{tabular}{lcccc}
\hline Samples & $\begin{array}{c}\mathrm{E}_{\mathrm{O}} \\
(10 \mathrm{mV})\end{array}$ & $\begin{array}{c}\mathrm{E}_{\mathrm{R}} \\
(10 \mathrm{mV})\end{array}$ & $\begin{array}{c}\mathrm{E}_{\mathrm{O}}-\mathrm{E}_{\mathrm{R}} \\
(10 \mathrm{mV}) \\
\text { reversibility }\end{array}$ & $\begin{array}{c}\text { Proton diffusion } \\
\text { coefficient }(\mathrm{D}) \\
\left(\times 10^{-7} \mathrm{~V}\right)\end{array}$ \\
\hline 4-qtpy & 0.0866 & 0.1583 & 0.0834 & 3.776 \\
Complex 1 & 0.1184 & 0.2018 & 0.0704 & 7.785 \\
Complex 3 & 0.1412 & 0.2116 & 0.0717 & 6.772 \\
\hline
\end{tabular}

In Fig. 1a-c, it has been shown that the increase in scan rate from $10-100 \mathrm{mV}$ enhances the redox potential along with the increase in reversibility. Complex 1 shows a high redox value with increased diffusion coefficient value compared to ligand and complex 3.

Due to the influence of electrolyte, smaller the oxidationreduction value $\left(E_{O}-E_{R}\right)$ greater will be the electrode activity, and greater is the diffusion coefficient (D) and greater will be the electrochemical performance [33,34].

DNA binding studies: It is well known that for many metal based drugs DNA is the primary target molecule. Therefore, study of binding mode of metal complexes with DNA is vital. The mode of binding of lanthanum(III) complexes 1-4 with HS-DNA are carried out by UV-visible absorption and viscosity method.

UV-visible absorption spectral studies: UV-visible absorption method is an effective method to determine the mode of binding of metal complexes with HS-DNA. In this experiment, the absorption spectra of the complexes were recorded by incremental addition of HS-DNA with constant complex concentration. The UV-visible spectra of lanthanum(III) terpyridine complexes in the absence and successive addition of HS-DNA are shown in Fig. 2. The spectra clearly show that the absorption bands of lanthanum complexes 1-4 have shown hypochromism with increasing concentration of DNA and slight bathochromic shift indicating the intercalative mode of binding [35]. The hypochromicity for the complexes 1-4 are 22.4-67.7\% and the slight red shift of 1-3 nm can be seen in the spectra [3]. This is due to a strong $\pi \rightarrow \pi *$ coupling between an aromatic chromophore of the complexes and the HS-DNA base pairs [7,36]. The $\mathrm{K}_{\mathrm{b}}$ (binding constant) values have been given in Table-2. The order $\mathbf{1}>\mathbf{3}>\mathbf{2}>\mathbf{4}$ follows the $\mathrm{K}_{\mathrm{b}}$ values in the range $10^{5}-10^{6} \mathrm{M}^{-1}$. The higher binding tendency of terpyridine complexes compared to phen complexes is due to the presence of extended planar aromatic ring in terpyridine [35]. The higher $\mathrm{K}_{\mathrm{b}}$ value of the complexes $\mathbf{1}$ and $\mathbf{3}$ are owed to less hindered coordination environment which facilitates easy intercalation between the complexes and the DNA base pairs.

Viscosity measurements: In the absence of crystallographic data this hydrodynamic method is used because this is the most convincing technique to specify the mode of binding of lanthanum(III) complexes to HS-DNA. Viscometric method is very sensitive to the complete variations in the contour length of DNA strands. In classical intercalators, owing to perception of the metal complex into nucleobases, there is an elongation in the length of DNA double helix, leads to increase in the HS-DNA viscosity [35,37]. Thus, the viscometric measurements were carried out by increasing the concentration of complexes 1-4, keeping HS-DNA as constant. In Fig. 3, changes in the length of DNA is observed with increase in the concentration of complexes 1-4 there by increase in the viscocity. Complex 1 has the highest viscocity which specifies its strong intercalating character. With these results, all the lanthanum(III) complexes 1-4 are intercalated in accordance with the other spectral results.

Chemical nuclease activity: The synthesized La(III) complexes in comparison with 4-qtpy were studied by agarose gel electrophoresis using pUC 19 DNA. By using synthesized $\mathrm{La}(\mathrm{III})$ complexes 1-4 $(10 \mu \mathrm{M})$, the super-coiled form (form I) of pUC 19 DNA can be converted into nicked form (form II) and then to linear form (form III) in an agarose gel by applying voltage. The DNA cleavage efficiency of complexes 1-4 can be recognized by conversion of supercoiled DNA into its nicked

TABLE-2

SELECTED PHYSICO-CHEMICAL DATA AND DNA BINDING PARAMETERS OF La(III) COMPLEXES 1-4

\begin{tabular}{|c|c|c|c|c|c|c|c|}
\hline \multirow{2}{*}{ Compd. } & \multicolumn{3}{|c|}{$\mathrm{IR}^{\mathrm{a}}\left(\mathrm{cm}^{-1}\right)$} & \multirow{2}{*}{$\begin{array}{l}\text { Absorption }{ }^{\mathrm{b}} \lambda_{\max } \\
\left(\varepsilon, \mathrm{dm}^{3} \mathrm{M}^{-1} \mathrm{~cm}^{-1}\right)\end{array}$} & \multirow{2}{*}{$\Lambda_{\mathrm{M}}^{\mathrm{c}}\left(\mathrm{S} \mathrm{cm}^{2} \mathrm{M}^{-1}\right)$} & \multirow{2}{*}{$K_{b}\left(M^{-1}\right)^{d}$} & \multirow{2}{*}{$\mathrm{H}(\%)^{\mathrm{e}}$} \\
\hline & $v(\mathrm{C}=\mathrm{N})$ & $v\left(\mathrm{NO}_{3}\right)$ (coordinated) & $v\left(\mathrm{NO}_{3}\right)^{-}$(ionic) & & & & \\
\hline 1 & 1600 & 1451,1314 & 1398 & $266(66,333)$ & 92 & $(4.2 \pm 0.2) \times 10^{6}$ & 57.6 \\
\hline 2 & 1578 & 1460,1322 & 1394 & $265(52,533)$ & 142 & $(5.3 \pm 0.2) \times 10^{5}$ & 67.7 \\
\hline 3 & 1572 & 1455,1308 & 1392 & $266(44,600)$ & 94 & $(1.4 \pm 0.2) \times 10^{6}$ & 26.6 \\
\hline 4 & 1580 & 1460,1315 & 1396 & $283(40,666)$ & 118 & $(2.9 \pm 0.2) \times 10^{5}$ & 22.4 \\
\hline
\end{tabular}

${ }^{\mathrm{a}} \mathrm{In} \mathrm{KBr}$ phase, ${ }^{\mathrm{b}}$ Absorption in DMF, ${ }^{\mathrm{c}} \Lambda_{\mathrm{M}}$, Molar conductivity in DMF at $25{ }^{\circ} \mathrm{C},{ }^{\mathrm{d}} \mathrm{K}_{\mathrm{b}}, \mathrm{HS}$-DNA binding constant, ${ }^{\mathrm{e}} \mathrm{H}=\left[\left(\mathrm{A}_{\text {free }}-\mathrm{A}_{\text {bound }}\right) / \mathrm{A}_{\text {free }}\right] \times 100$ 

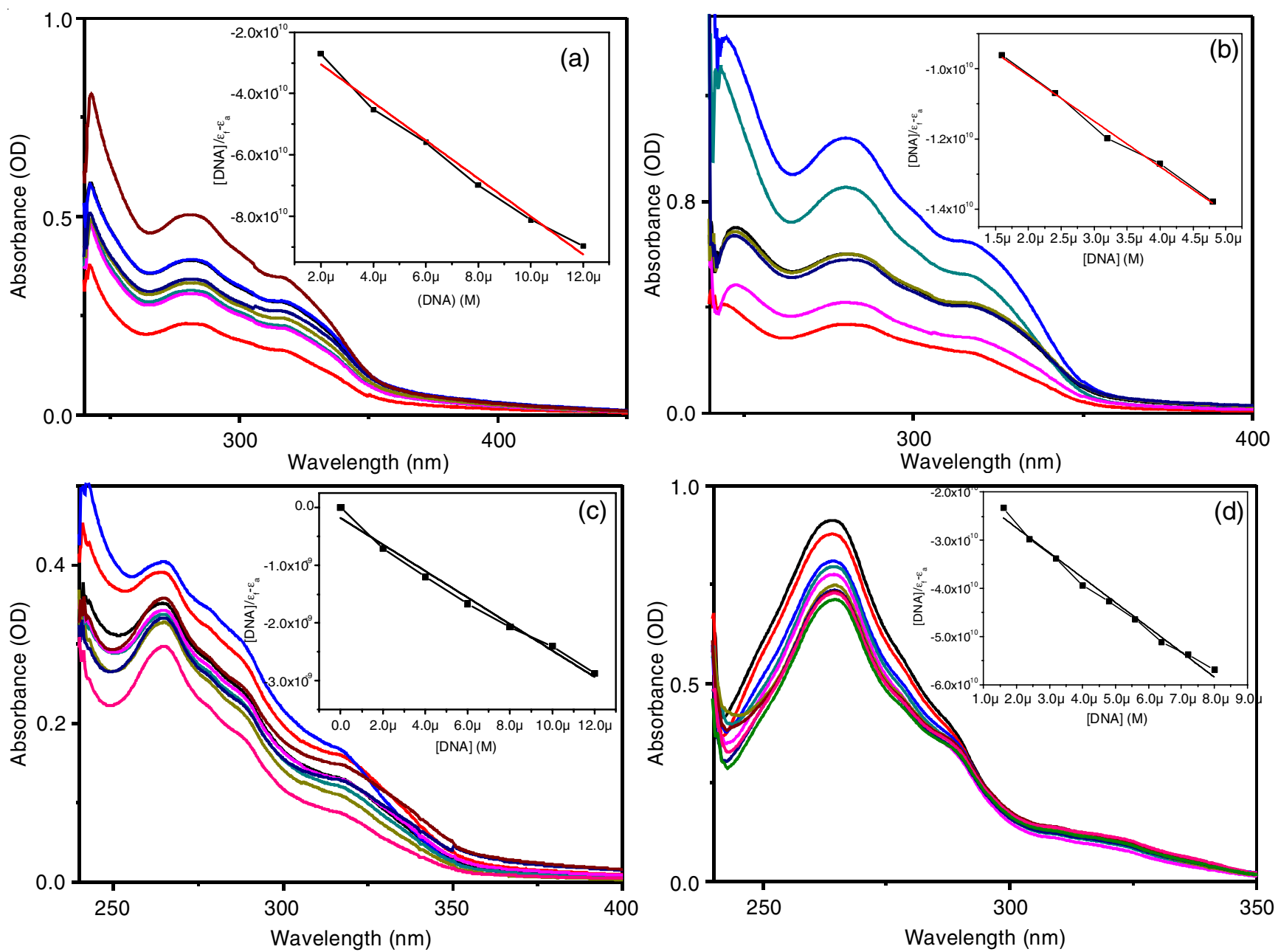

Fig. 2. UV-visible absorption spectra of complexes $\mathbf{1}$ (a), 2 (b), 3 (c) and $\mathbf{4}$ (d) in the absence and presence of HS-DNA in $5 \mathrm{mM} \mathrm{Tris-HCl/50}$ $\mathrm{mM} \mathrm{NaCl}$ buffer $(\mathrm{pH} 7.2)$ at $25^{\circ} \mathrm{C}$. The inset shows the plot of [DNA] $v$. [DNA] $/ \varepsilon_{\mathrm{a}}-\varepsilon_{\mathrm{f}}$

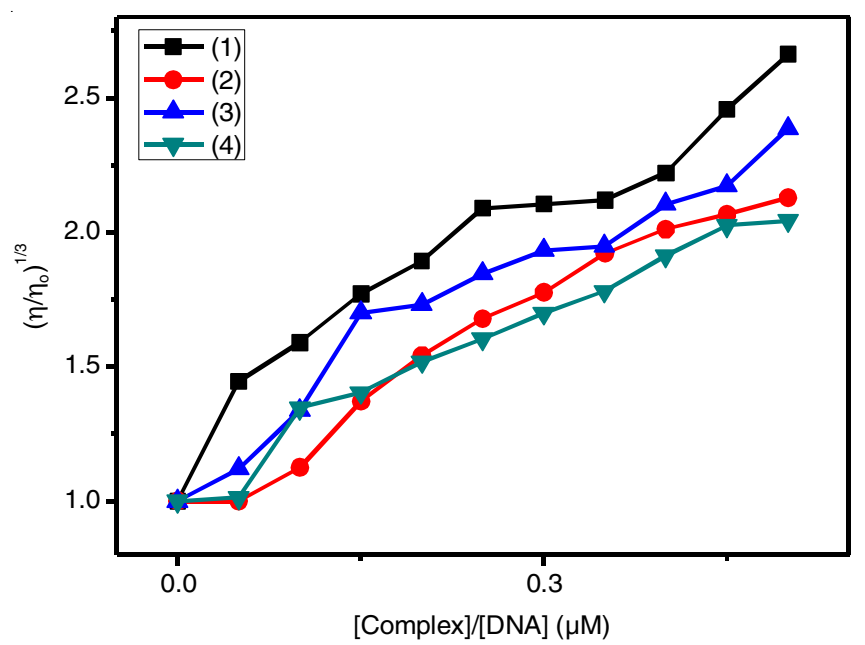

Fig. 3. Effect of increasing conc. of complexes on the relative viscosity of HS-DNA at $37.0( \pm 0.1){ }^{\circ} \mathrm{C}$ in $5 \mathrm{mM}$ Tris- $\mathrm{HCl}$ buffer $\mathrm{pH} 7.2$ form and linear form. Fig. 4 displays the electrophoretic array of plasmid DNA treated with 4-qtpy and its $\mathrm{La}$ (III) complexes 1-4. In agarose gel, super coiled DNA moves faster than nicked circular while linear form moves in between them. From Fig. 4 , there is no significant DNA cleavage for controls, DNA alone and in the presence of oxidizing agent $\mathrm{H}_{2} \mathrm{O}_{2}$ and reducing agent MPA (lanes 1-3). Complexes 3 and $\mathbf{4}$ showed the maximum cleavage activity (lanes 14 and 17) in the presence of $\mathrm{H}_{2} \mathrm{O}_{2}$ and showed moderate cleavage activity (lanes 15 and 18) in the presence of MPA. Complexes $\mathbf{1}$ and $\mathbf{2}$ showed a moderate cleavage activity (lanes 9 and 12) in the presence MPA (Table-3) [38,39].

The concentration dependent experiment for complex 5 at 5 , 7 and $10 \mu \mathrm{M}$ concentration are shown in Fig. 5. The complex 4 showed a weak cleavage activity at conc. 5 and $7 \mu \mathrm{M}$ and the maximum activity at $10 \mu \mathrm{M}$ (Table-4). The mechanistic study of oxidative cleavage (Fig. 6) was studied using the hydroxyl

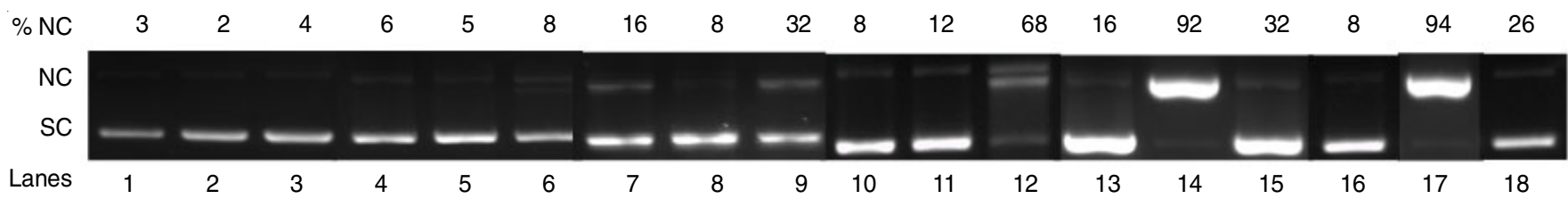

Fig. 4. Agarose gel electrophoretic diagram of 4-qtpy and its La(III) complexes $\mathbf{1 - 4}$ at $10 \mu \mathrm{M}$ by hydrolytic and oxidative cleavage methods in presence $\mathrm{H}_{2} \mathrm{O}_{2}$ and MPA and $50 \mathrm{mM}$ Tris- $\mathrm{HCl} / \mathrm{NaCl}$ buffer $(\mathrm{pH}=7.2)$ at $37^{\circ} \mathrm{C}$ 


\begin{tabular}{|c|c|c|c|c|c|c|c|c|c|c|c|c|}
\hline$\%$ NC & 4 & 3 & 4 & 8 & 36 & 12 & 10 & 62 & 16 & 4 & 94 & 8 \\
\hline NC & & & & & 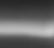 & & & 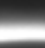 & & & & \\
\hline SC & & & & & & & & & & & & \\
\hline Lanes & 1 & 2 & 3 & 4 & 5 & 6 & 7 & 8 & 9 & 10 & 11 & 12 \\
\hline
\end{tabular}

Fig. 5. Agarose gel electrophoretic diagram showing SC pUC 19 DNA cleavage by $\left[\mathrm{La}(4-\mathrm{qtpy})(\mathrm{phen})\left(\mathrm{NO}_{3}\right)_{2}\right]\left(\mathrm{NO}_{3}\right)(3)$ at concentration 5,7 , $10 \mu \mathrm{M}$ by hydrolytic and oxidative cleavage methods in presence of $50 \mathrm{mM}$ Tris- $\mathrm{HCl} / \mathrm{NaCl}$ buffer $(\mathrm{pH}=7.2)$ at $37^{\circ} \mathrm{C}$

TABLE-3

SC pUC 19 DNA CLEAVAGE DATA OF 4-qtpy AND ITS La(III) COMPLEXES 1-4

\begin{tabular}{|c|c|c|c|}
\hline $\begin{array}{c}\text { Lane } \\
\text { no. }\end{array}$ & Conditions & $\begin{array}{l}\mathrm{SC} \\
(\%)\end{array}$ & $\begin{array}{l}\mathrm{NC} \\
(\%)\end{array}$ \\
\hline 1 & $\mathrm{DNA}+\mathrm{NaCl}+$ Tris $\mathrm{HCl}$ & 97 & 3 \\
\hline 2 & $\mathrm{DNA}+\mathrm{NaCl}+$ Tris $\mathrm{HCl}+\mathrm{H}_{2} \mathrm{O}_{2}$ & 98 & 2 \\
\hline 3 & $\mathrm{DNA}+\mathrm{NaCl}+$ Tris $\mathrm{HCl}+\mathrm{MPA}$ & 96 & 4 \\
\hline 4 & $\mathrm{DNA}+\mathrm{NaCl}+$ Tris $\mathrm{HCl}+4-\mathrm{qtpy}$ & 94 & 6 \\
\hline 5 & $\mathrm{DNA}+\mathrm{NaCl}+$ Tris $\mathrm{HCl}+\mathrm{H}_{2} \mathrm{O}_{2}+4$-qtpy & 95 & 5 \\
\hline 6 & $\mathrm{DNA}+\mathrm{NaCl}+$ Tris $\mathrm{HCl}+\mathrm{MPA}+4-\mathrm{qtpy}$ & 92 & 8 \\
\hline 7 & $\mathrm{DNA}+\mathrm{NaCl}+$ Tris $\mathrm{HCl}+\mathbf{1}$ & 84 & 16 \\
\hline 8 & $\mathrm{DNA}+\mathrm{NaCl}+$ Tris $\mathrm{HCl}+\mathrm{H}_{2} \mathrm{O}_{2}+\mathbf{1}$ & 92 & 8 \\
\hline 9 & $\mathrm{DNA}+\mathrm{NaCl}+$ Tris $\mathrm{HCl}+\mathrm{MPA}+\mathbf{1}$ & 68 & 32 \\
\hline 10 & $\mathrm{DNA}+\mathrm{NaCl}+$ Tris $\mathrm{HCl}+\mathbf{2}$ & 92 & 8 \\
\hline 11 & $\mathrm{DNA}+\mathrm{NaCl}+$ Tris $\mathrm{HCl}+\mathrm{H}_{2} \mathrm{O}_{2}+2$ & 88 & 12 \\
\hline 12 & $\mathrm{DNA}+\mathrm{NaCl}+$ Tris $\mathrm{HCl}+\mathrm{MPA}+2$ & 32 & 68 \\
\hline 13 & $\mathrm{DNA}+\mathrm{NaCl}+$ Tris $\mathrm{HCl}+\mathbf{3}$ & 84 & 16 \\
\hline 14 & $\mathrm{DNA}+\mathrm{NaCl}+$ Tris $\mathrm{HCl}+\mathrm{H}_{2} \mathrm{O}_{2}+\mathbf{3}$ & 8 & 92 \\
\hline 15 & $\mathrm{DNA}+\mathrm{NaCl}+$ Tris $\mathrm{HCl}+\mathrm{MPA}+\mathbf{3}$ & 68 & 32 \\
\hline 16 & $\mathrm{DNA}+\mathrm{NaCl}+$ Tris $\mathrm{HCl}+4$ & 92 & 8 \\
\hline 17 & $\mathrm{DNA}+\mathrm{NaCl}+$ Tris $\mathrm{HCl}+\mathrm{H}_{2} \mathrm{O}_{2}+4$ & 6 & 94 \\
\hline 18 & $\mathrm{DNA}+\mathrm{NaCl}+$ Tris $\mathrm{HCl}+\mathrm{MPA}+4$ & 74 & 26 \\
\hline
\end{tabular}

TABLE-4

CONCENTRATION DEPENDENT SC pUC 19 DNA CLEAVAGE DATA OF $\left[\mathrm{La}(4-\mathrm{qtpy})(\mathrm{phen})\left(\mathrm{NO}_{3}\right)_{2}\right]\left(\mathrm{NO}_{3}\right)(3)$

\begin{tabular}{clcc}
\hline $\begin{array}{c}\text { Lane } \\
\text { no. }\end{array}$ & \multicolumn{1}{c}{ Conditions } & $\begin{array}{c}\text { SC } \\
(\%)\end{array}$ & $\begin{array}{c}\mathrm{NC} \\
(\%)\end{array}$ \\
\hline 1 & $\mathrm{DNA}+\mathrm{NaCl}+$ Tris $\mathrm{HCl}$ & 96 & 4 \\
2 & $\mathrm{DNA}+\mathrm{NaCl}+$ Tris $\mathrm{HCl}+\mathrm{H}_{2} \mathrm{O}_{2}$ & 97 & 3 \\
3 & $\mathrm{DNA}+\mathrm{NaCl}+$ Tris $\mathrm{HCl}+\mathrm{MPA}$ & 96 & 4 \\
4 & $\mathrm{DNA}+\mathrm{NaCl}+$ Tris $\mathrm{HCl}+5 \mu \mathrm{M}$ & 92 & 8 \\
5 & $\mathrm{DNA}+\mathrm{NaCl}+$ Tris $\mathrm{HCl}+\mathrm{H}_{2} \mathrm{O}_{2}+5 \mu \mathrm{M}$ & 64 & 36 \\
6 & $\mathrm{DNA}+\mathrm{NaCl}+$ Tris $\mathrm{HCl}+\mathrm{MPA}+5 \mu \mathrm{M}$ & 88 & 12 \\
7 & $\mathrm{DNA}+\mathrm{NaCl}+$ Tris $\mathrm{HCl}+7 \mu \mathrm{M}$ & 90 & 10 \\
8 & $\mathrm{DNA}+\mathrm{NaCl}+$ Tris $\mathrm{HCl}+\mathrm{H}_{2} \mathrm{O}_{2}+7 \mu \mathrm{M}$ & 38 & 62 \\
9 & $\mathrm{DNA}+\mathrm{NaCl}+$ Tris $\mathrm{HCl}+\mathrm{MPA}^{2}+7 \mu \mathrm{M}$ & 84 & 16 \\
10 & $\mathrm{DNA}+\mathrm{NaCl}+$ Tris $\mathrm{HCl}+10 \mu \mathrm{M}$ & 96 & 4 \\
11 & $\mathrm{DNA}+\mathrm{NaCl}+$ Tris $\mathrm{HCl}+\mathrm{H}_{2} \mathrm{O}_{2}+10 \mu \mathrm{M}$ & 6 & 94 \\
12 & $\mathrm{DNA}+\mathrm{NaCl}+$ Tris $\mathrm{HCl}+\mathrm{MPA}+10 \mu \mathrm{M}$ & 92 & 8 \\
\hline
\end{tabular}

$[\mathrm{NaCl}]=50 \mathrm{mM} ;[$ Tris- $\mathrm{HCl}]=50 \mathrm{mM} ;\left[\mathrm{H}_{2} \mathrm{O}_{2}\right]=200 \mu \mathrm{M} ;[\mathrm{MPA}]=$ $500 \mu \mathrm{M} ;[$ Complex] $=10 \mu \mathrm{M}$

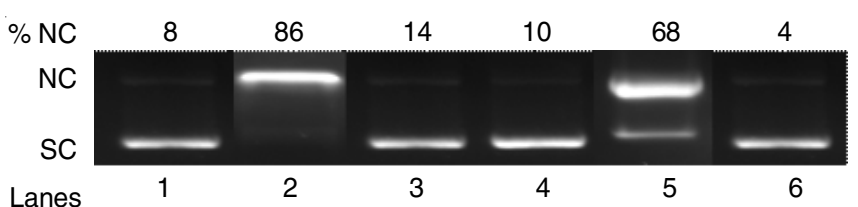

Fig. 6. Agarose gel electrophoretic diagram showing SC pUC 19 DNA cleavage in the presence of $\mathrm{H}_{2} \mathrm{O}_{2}, 50 \mathrm{mM}$ Tris- $\mathrm{HCl} / \mathrm{NaCl}$ buffer $(\mathrm{pH}$ $=7.2)$ and additives (DMSO, $\mathrm{NaN}_{3}$ and methyl green $(\mathrm{MG})$ ) by $[\mathrm{La}(4-$ qtpy)(phen) $\left.\left(\mathrm{NO}_{3}\right)_{2}\right]\left(\mathrm{NO}_{3}\right)(3)$ and of $\left[\mathrm{La}(4 \mathrm{qtpy})(\text { phen })_{2}\left(\mathrm{NO}_{3}\right)_{2}\right]\left(\mathrm{NO}_{3}\right)$ (4) radical quencher DMSO, singlet oxygen quencher $\mathrm{NaN}_{3}$ and major groove intercalator, methyl green in the presence of $\mathrm{H}_{2} \mathrm{O}_{2}$. From the results (Table-5), it is observed that the cleavage ability of complexes is inhibited in presence of hydroxyl radical quencher DMSO. Thus, it is confirmed that oxidative cleavage is mediated by the generation of hydroxyl radicals. It is also confirmed that major groove binder methyl green inhibits the cleavage ability of complexes 3 and $\mathbf{4}$. This showed that the complexes $\mathbf{3}$ and $\mathbf{4}$ are the major groove intercalators $[13,40]$.

\begin{tabular}{cccc}
\multicolumn{5}{c}{ TABLE-5 } \\
\multicolumn{5}{c}{$\begin{array}{c}\text { MECHANISTIC STUDY OF COMPLEXES } \\
\text { 3 AND 4 WITH pUC 19 DNA }\end{array}$} \\
\hline $\begin{array}{c}\text { Lane } \\
\text { no. }\end{array}$ & \multicolumn{1}{c}{ Conditions } & SC & NC \\
$(\%)$ & $(\%)$ \\
\hline 1 & $\mathrm{DNA}+\mathrm{NaCl}+$ Tris $\mathrm{HCl}+\mathrm{H}_{2} \mathrm{O}_{2}+\mathrm{DMSO}+\mathbf{3}$ & 92 & 8 \\
2 & $\mathrm{DNA}+\mathrm{NaCl}+$ Tris $\mathrm{HCl}+\mathrm{H}_{2} \mathrm{O}_{2}+\mathrm{NaN}_{3}+\mathbf{3}$ & 14 & 86 \\
3 & $\mathrm{DNA}+\mathrm{NaCl}+$ Tris $\mathrm{HCl}+\mathrm{H}_{2} \mathrm{O}_{2}+\mathrm{MG}+\mathbf{3}$ & 86 & 14 \\
4 & $\mathrm{DNA}+\mathrm{NaCl}+$ Tris $\mathrm{HCl}+\mathrm{H}_{2} \mathrm{O}_{2}+\mathrm{DMSO}+\mathbf{4}$ & 90 & 10 \\
5 & $\mathrm{DNA}+\mathrm{NaCl}+$ Tris $\mathrm{HCl}+\mathrm{H}_{2} \mathrm{O}_{2}+\mathrm{NaN}+\mathbf{4}$ & 72 & 68 \\
6 & $\mathrm{DNA}+\mathrm{NaCl}+$ Tris $\mathrm{HCl}+\mathrm{H}_{2} \mathrm{O}_{2}+\mathrm{MG}+\mathbf{4}$ & 96 & 4 \\
\hline
\end{tabular}

$[\mathrm{NaCl}]=50 \mathrm{mM} ;[$ Tris- $\mathrm{HCl}]=50 \mathrm{mM} ;\left[\mathrm{H}_{2} \mathrm{O}_{2}\right]=200 \mu \mathrm{M} ;[\mathrm{MPA}]=$ $500 \mu \mathrm{M} ;[$ Complex $]=10 \mu \mathrm{M}$.

Antibacterial activity: $4^{\prime}-\left[(4-Q u i n o l i n e)-2,2^{\prime} ; 6^{\prime}, 2^{\prime \prime}\right.$ terpyridine] (4-qtpy) and its $\mathrm{La}$ (III) complexes $\mathbf{1 - 4}$ are screened for antibacterial activities against Gram negative bacteria $E$. coli and $K$. pneumonia and Gram positive bacteria B. subtilis and $S$. aureus, respectively. Tetracycline $\left(30 \mu \mathrm{g} \mathrm{mL}^{-1}\right)$ is used as positive control and DMSO is used as negative control [10]. The activities of the La(III) complexes are evidenced from zone of inhibition. The ligand, 4-qtpy shows moderate activity against $E$. coli and $S$. aureus and minimum activity against B. subtilis and $K$. pneumonia at 50 and $100 \mu \mathrm{gL}^{-1}$ (Fig. 7). Complexes $\mathbf{1}$ and $\mathbf{3}$ show moderate activity against all the bacteria and complex $\mathbf{3}$ shows maximum activity against $K$. pneumonia at $50 \mu \mathrm{g} \mathrm{mL}^{-1}$, complex 2 shows minimum activity against all the bacteria while complex $\mathbf{4}$ shows maximum activity against $E$. coli and $S$. aureus at $50 \mu \mathrm{g} \mathrm{mL}^{-1}$ and it shows moderate activity against other bacteria. All the complexes showed significant antibacterial activities against all the tested bacteria [41].

in vitro Cytotoxicity: The cytotoxicity of 4-qtpy and complex $\mathbf{4}$ are evaluated against human cervical carcinoma (HeLa) cell line by MTT assay. Increase in the concentration of samples increases the percentage of inhibition. The ligand 4-qtpy did not show any activity against HeLa cell lines. The complex 4 shows in vitro cytotoxic activity against $\mathrm{HeLa}$ cell line with an $\mathrm{IC}_{50}$ value of $179.4 \mu \mathrm{M}$. These results suggested that the cytotoxicity depends upon the nature of bidentate and tridentate ligand coordinated to the metal center [42]. Fig. 8 shows that the increase in concentration of drug increases the percentage of inhibition. 
E. coli

$\backsim 30=50=100$

(a)

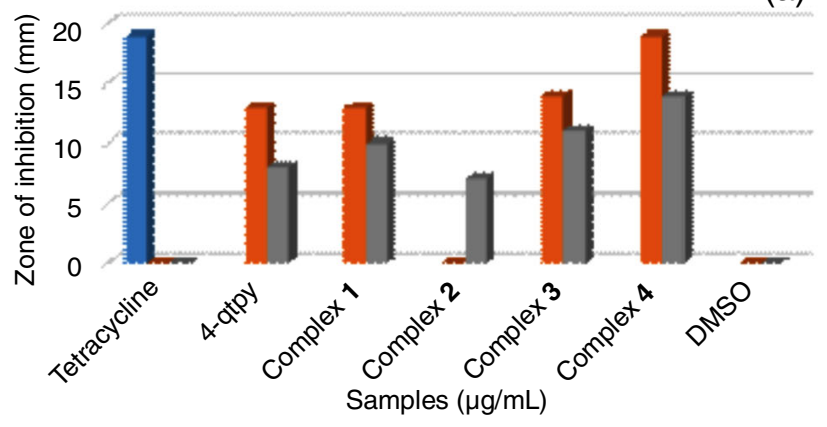

S. aureus $\because 30=50=100$

(c)

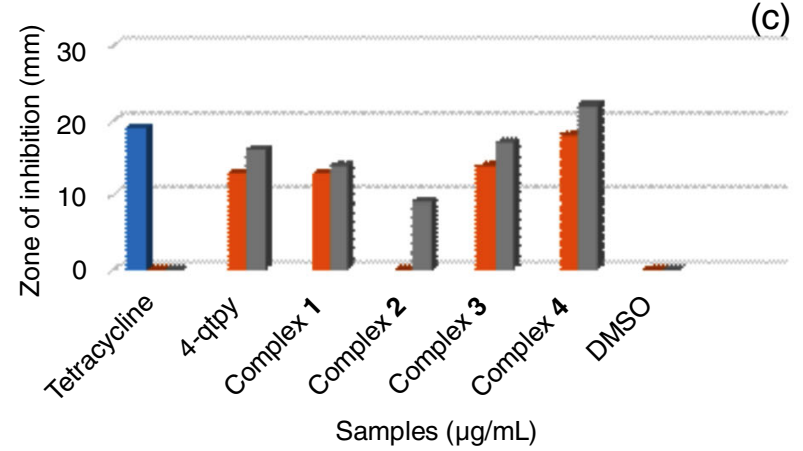

K. pneumonia

$\square 30=50=100$

(b)

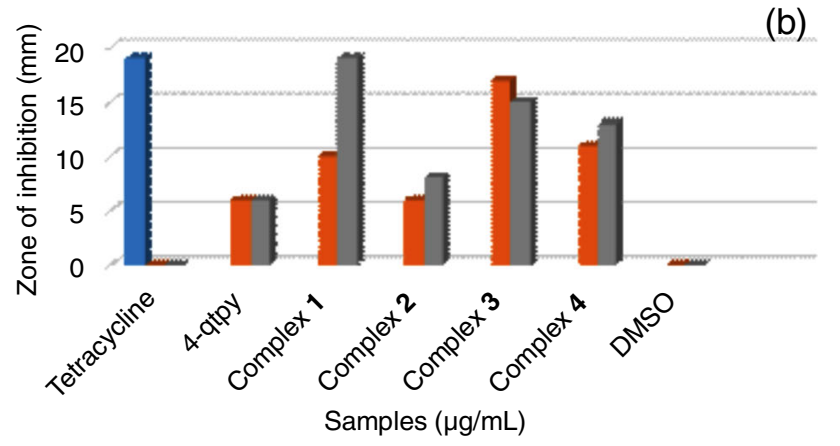

B. subtillis $=30 \backsim 50=100$

(d)

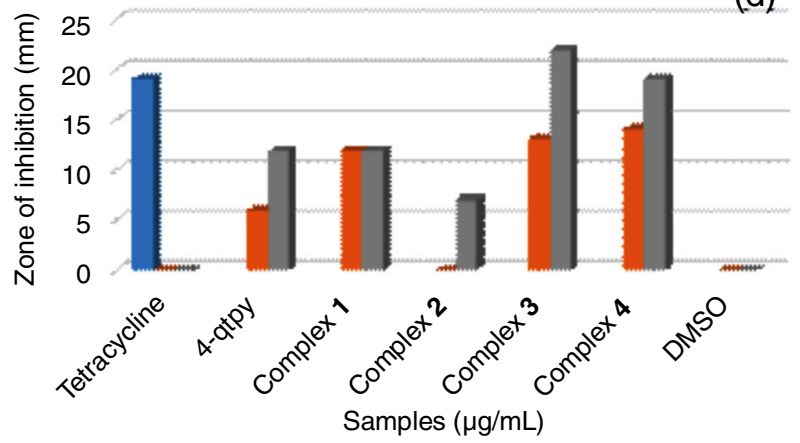

Fig. 7. A bar diagram showing antibacterial activities of 4-qtpy and its La(III) complexes 1-4 against gram negative bacteria (E. coli and $K$. pneumonia) and Gram-positive bacteria (S. aureus and B. subtillis) at concentration $50 \mu \mathrm{g} \mathrm{mL}^{-1}$ and $100 \mu \mathrm{g} \mathrm{mL} L^{-1}$. Tetracycline is used as positive control $\left(30 \mu \mathrm{g} \mathrm{mL} \mathrm{m}^{-1}\right)$ and DMSO is used as negative control

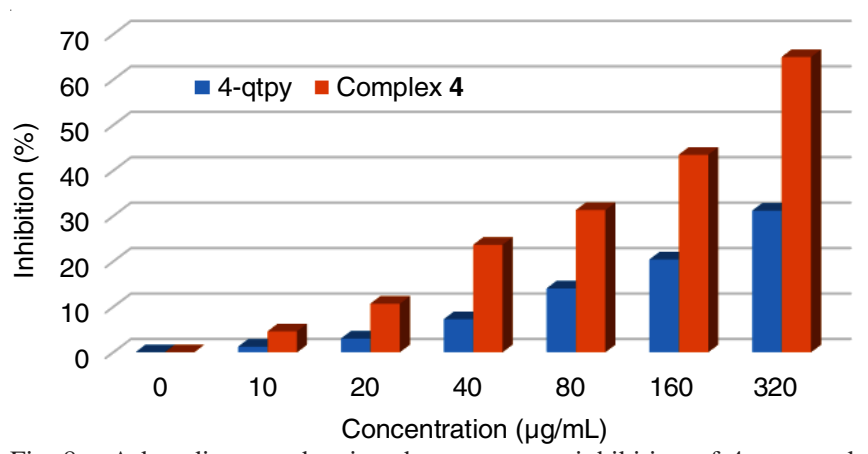

Fig. 8. A bar diagram showing the percentage inhibition of 4-qtpy and complex $\mathbf{4}$ at varying concentration against HeLa cell lines

\section{Conclusion}

In present work, we have synthesized four $\mathrm{La}(\mathrm{III})$ complexes with 4-quinoline terpyridines. All the complexes were structurally confirmed by their elemental analyses and spectrochemical analyses such as ${ }^{1} \mathrm{H}$ NMR, FT-IR, UV-visible spectra and ESI-mass spectra. The ligand 4-qtpy and complexes 1 and $\mathbf{3}$ are redox active. The peak current increases with the increase in scan rate and is significantly correlated with the square root of the scan rate. The complex $\mathbf{1}$ shows high redox activity value compared to complex 3 and 4-qtpy. [La(4-qtpy $\left.)_{2}\left(\mathrm{NO}_{3}\right)_{2}\right]\left(\mathrm{NO}_{3}\right)$ (1) and $\left[\mathrm{La}(4-\mathrm{qtpy})(\right.$ phen $\left.)\left(\mathrm{NO}_{3}\right)_{2}\right]\left(\mathrm{NO}_{3}\right)(3)$ complexes showed very good binding and cleavage activity and they also shown ligand dependent fluorescence properties. The complex $\mathbf{1}$ also shown good antibacterial activity against $K$. pneumonia and complex 2 shows good activity against $K$. pneumonia and $B$. subtillis. The complex 4 viz. [La(4-qtpy)(phen $\left.)_{2}\left(\mathrm{NO}_{3}\right)_{2}\right]\left(\mathrm{NO}_{3}\right)$ showed a good activity against $E$. coli and $S$. aureus pathogens. Thus, these complexes can be employed as potent therapeutic and diagnostic tools.

\section{ACKNOWLEDGEMENTS}

The authors greatly acknowledge Prof. Dr. Nils MetzlerNolte, Chair of Inorganic Chemistry, Ruhr-University, Bochum, Germany for providing ESI-MS facility. The authors also greatly acknowledge Dr. T. Demappa, Associate Prof., Department of Polymer science, University of Mysore, Mysore, India and Dr. Y. Shivaraj, Assistant Prof., Government Science College, Bengaluru, India for providing spectroscopic facilities. One of the authors, Navya greatly acknowledges the UGC for providing RGNF fellowship to carry out this research work. Another author P.R. Chetana acknowledges DST for equipping her laboratory with Gel-Documentation system and also acknowledges to UGC for providing electrochemical work station.

\section{CONFLICT OF INTEREST}

The authors declare that there is no conflict of interests regarding the publication of this article.

\section{REFERENCES}

1. R. Indumathy, S. Radhika, M. Kanthimathi, T. Weyhermuller and B. Unni Nair, J. Inorg. Biochem., 101, 434 (2007); https://doi.org/10.1016/j.jinorgbio.2006.11.002.

2. D. Mahendiran, R.S. Kumar, V. Viswanathan, D. Velmurugan and A.K. Rahiman, J. Chem. Soc., Dalton Trans., 45, 7794 (2016); https://doi.org/10.1039/C5DT03831F. 
3. S. Ghosh, Z. Abbas, S. Dasari and A.K. Patra, J. Lumin., 187, 46 (2017); https://doi.org/10.1016/j.jlumin.2017.02.063.

4. P. Ponya Utthra, G. Kumaravel, R. Senthilkumar and N. Raman, Appl. Organomet. Chem., 31, e3629 (2017);

https://doi.org/10.1002/aoc.3629.

5. F. Darabi, H. Hadadzadeh, J. Simpson and A. Shahpiri, New J. Chem., 40, 9081 (2016);

https://doi.org/10.1039/C6NJ01880G.

6. S. Rajalakshmi, T. Weyhermüller, A.J. Freddy, H.R. Vasanthi and B.U. Nair, Eur. J. Med. Chem., 46, 608 (2011); https://doi.org/10.1016/j.ejmech.2010.11.041.

7. P.R. Inamdar and A. Sheela, J. Photochem. Photobiol. B, 159, 133 (2016); https://doi.org/10.1016/j.jphotobiol.2016.03.007.

8. Q. Jiang, J. Zhu, Y. Zhang, N. Xiao and Z. Guo, Biometals, 22, 297 (2009);

https://doi.org/10.1007/s10534-008-9166-3.

9. V.M. Manikandamathavan and B. Unni Nair, Eur. J. Med. Chem., 68, 244 (2013); https://doi.org/10.1016/i.eimech.2013.07.051

10. G. Zhao, F. Li, H. Lin and H. Lin, Bioorg. Med. Chem., 15, 533 (2007); https://doi.org/10.1016/j.bmc.2006.09.032.

11. J. Zhou, L. Wang, J.-y. Wang and N. Tang, J. Inorg. Biochem., 83, 41 (2001); https://doi.org/10.1016/S0162-0134(00)00128-8.

12. B. Wang, Z.-Y. Yang, D. Qin and Z.-N. Chen, J. Photochem. Photobiol. Chem., 194, 49 (2008); https://doi.org/10.1016/j.jphotochem.2007.07.024.

13. P.R. Chetana, V.V. Bhat and M.A. Dhale, Int. J. Pharm. Sci. Rev. Res., 49, 86 (2018).

14. S.Y. Shaban, M.A. El-Kemary, G. Samir, H. El-Baradei and R. Puchta, J. Coord. Chem., 68, 3247 (2015); https://doi.org/10.1080/00958972.2015.1065320.

15. A. Hussain, S. Gadadhar, T.K. Goswami, A.A. Karande and A.R. Chakravarty, J. Chem. Soc., Dalton Trans., 41, 885 (2012); https://doi.org/10.1039/C1DT11400J.

16. E.-J. Gao, Q. Yao, M.-C. Zhu, D. Zhang, M.-Y. Li, H. Fu, M.-P. Jiang, H.-L. Yan, X.-Y. Xun, L. Zhan and H. Wang, J. Coord. Chem., 67, 2086 (2014); https://doi.org/10.1080/00958972.2014.935354.

17. A. Hussain, K. Somyajit, B. Banik, S. Banerjee, G. Nagaraju and A.R. Chakravarty, J. Chem. Soc., Dalton Trans., 42, 182 (2013); https://doi.org/10.1039/C2DT32042H.

18. H.R. Mürner, E. Chassat, R.P. Thummel and J.C.G. Bünzli, J. Chem. Soc., Dalton Trans., 2809 (2000); https://doi.org/10.1039/b003577g.

19. H. Cui and C. Cui, J. Chem. Soc., Dalton Trans., 40, 11937 (2011); https://doi.org/10.1039/c1dt11592h.

20. S. Roy, S. Saha, R. Majumdar, R.R. Dighe and A.R. Chakravarty, Polyhedron, 29, 2787 (2010); https://doi.org/10.1016/j.poly.2010.06.028.

21. B. Jiang, M. Wang, C. Li and J. Xie, Med. Chem. Res., 22, 3398 (2013); https://doi.org/10.1007/s00044-012-0357-7.

22. V.G. Vaidyanathan and B.U. Nair, J. Inorg. Biochem., 94, 121 (2003); https://doi.org/10.1016/S0162-0134(02)00620-7.

23. P.R. Chetana, R. Rao, D. Lahiri, R.S. Policegoudra, R. Sankolli and M.S. Aradhya, Polyhedron, 68, 172 (2014); https://doi.org/10.1016/j.poly.2013.10.025.
24. P.R. Chetana, B.S. Srinatha, M.N. Somashekar and R.S. Policegoudra, J. Mol. Struct., 1106, 352 (2016); https://doi.org/10.1016/j.molstruc.2015.10.010.

25. M.N. Patel, P.A. Dosi and B.S. Bhatt, Polyhedron, 29, 3238 (2010); https://doi.org/10.1016/i.poly.2010.08.037.

26. M.A. Dhale, S. Divakar, S. Umesh-Kumar and G. Vijayalakshmi, J. Appl. Microbiol., 103, 2168 (2007); https://doi.org/10.1111/j.1365-2672.2007.03457.x.

27. M. Gaye, F.B. Tamboura and A.S. Sall, Bull. Chem. Soc. Ethiop., 17, 27 (2003); https://doi.org/10.4314/bcse.v17i1.61726.

28. P.G. Avaji, B.N. Reddy, S.A. Patil and P.S. Badami, Transition Met. Chem., 31, 842 (2006); https://doi.org/10.1007/s11243-006-0066-5.

29. H. Xie and G. Lu, J. Rare Earths, 31, 639 (2013); https://doi.org/10.1016/S1002-0721(12)60334-2.

30. C.-W. Jiang, H. Chao, H. Li and L.-N. Ji, J. Inorg. Biochem., 93, 247 (2003); https://doi.org/10.1016/S0162-0134(02)00577-9.

31. P.C. Mondal and A.K. Manna, New J. Chem., 40, 5775 (2016); https://doi.org/10.1039/C5NJ03106K.

32. X. Huang, S. Guo, Q. Zhou, T. Lu and X. Ding, J. Electroanal. Chem., 600, 227 (2007); https://doi.org/10.1016/j.jelechem.2006.10.017.

33. M. Mylarappa, V.V. Lakshmi, K.R. Vishnu Mahesh, S. Kantharaju and S. Sreenivasa, Res. J. Chem. Environ., 22, 1 (2018).

34. M. Mylarappa, V.V. Lakshmi, K.R. Vishnu Mahesh, H.P. Nagaswarupa and N. Raghavendra, IOP Conf. Series: Mater. Sci. Eng., 149, 012178 (2016); https://doi.org/10.1088/1757-899X/149/1/012178.

35. V.M. Manikandamathavan, M. Thangaraj, T. Weyhermuller, R.P. Parameswari, V. Punitha, N.N. Murthy and B.U. Nair, Eur. J. Med. Chem., 135, 434 (2017); https://doi.org/10.1016/j.ejmech.2017.04.030.

36. Y.-N. Shi, K. Zheng, L. Zhu, Y.-T. Li, Z.-Y. Wu and C.-W. Yan, J. Biochem. Mol. Toxicol., 29, 221 (2015); https://doi.org/10.1002/jbt.21688.

37. V. Uma, M. Elango and B.U. Nair, Eur. J. Inorg. Chem., 2007, 3484 (2007); https://doi.org/10.1002/ejic.200700053.

38. B. Maity, M. Roy, B. Banik, R. Majumdar, R.R. Dighe and A.R. Chakravarty, Organometallics, 29, 3632 (2010); https://doi.org/10.1021/om100524x.

39. S. Roy, S. Roy, S. Saha, R. Majumdar, R.R. Dighe, E.D. Jemmis and A.R. Chakravarty, J. Chem. Soc., Dalton Trans., 40, 1233 (2011); https://doi.org/10.1039/C0DT00223B.

40. A.K. Patra, T. Bhowmick, S. Roy, S. Ramakumar and A.R. Chakravarty, Inorg. Chem., 48, 2932 (2009); https://doi.org/10.1021/ic8017425.

41. T. Ezhilarasu, A. Sathiyaseelan, P.T. Kalaichelvan and S. Balasubramanian, J. Mol. Struct., 1134, 265 (2017); https://doi.org/10.1016/j.molstruc.2016.12.102.

42. M.M. Milutinovic, A. Rilak, I. Bratsos, O. Klisuric, M. Vranes, N. Gligorijevic, S. Radulovic and Z.D. Bugarèic, J. Inorg. Biochem., 169, 1 (2017); https://doi.org/10.1016/j.jinorgbio.2016.10.001. 